\title{
Fertility Variation and its Implications on Relatedness in Seed Crops in Seedling Seed Orchards of Eucalyptus camaldulensis and E. tereticornis
}

\author{
By R. KAMALAKANNAN ${ }^{1)}$, M. VARGHeSE ${ }^{1, *)}$ and D. LinDGReN ${ }^{2)}$
}

(Received $5^{\text {th }}$ July 2006)

\begin{abstract}
Seedling seed orchards of Eucalyptus tereticornis $(\mathrm{N}=192 \& 505)$ and $E$. camaldulensis $(\mathrm{N}=182 \& 525)$ were established at two sites (one moist and one dry) in southern India. The fertility (based on the number of flowers and fruits) was registered for each tree at age eight and nine years. E. camaldulensis on the moist location had $73 \%$ fertile trees and low fertility difference (sibling coefficient, $\Psi$, was 2.27) at eight years. whereas Only $23 \%$ trees were fertile in the $E$. tereticornis orchard at the same site and the fertility variation was high $(\Psi=11.71)$. In the dry location, fertility was almost the same in both species at nine years, with $45 \& 51 \%$ fertile trees in $E$. camaldulensis $(\Psi=5.4)$ and $E$. tereticornis $(\Psi=5.2)$ respectively. Though the fertility trends were the same in both years, the number of fertile trees was comparatively higher at nine years (except in the low flowering $E$. tereticornis orchard at the moist site) in both the sites. Gene diversity values of the seed crop estimated for two consecutive years are fairly high except for the $E$. tereticornis $(\mathrm{GD}=0.9650$ and 0.9690$)$ orchard located in the moist site. The implications of fertility variation on diversity of progeny have been discussed in the light of domestication strategies and tree breeding programs implemented for eucalypts.
\end{abstract}

Key words: Eucalyptus camaldulensis, E. tereticornis, effective population size, seed orchard, gene diversity, drift, coancestry.

\section{Introduction}

India is one of the largest growers of eucalypts in the world (MidGLeY et al., 2002). The Indian land race Mysore gum that is considered to be a mixture of $E$. tereticornis and several other species is the major planted eucalypt (KAIKINI, 1961) in the country. The current productivity of eucalypt plantations under Indian conditions averages around $7 \mathrm{~m}^{3} / \mathrm{ha}$ /year (CHANDRA et al., 1992), which seems much below its potential. Eucalypts are extensively raised in arid and semi-arid regions of India for a wide range of uses such as pulp, scaffolding, temporary construction and small timber. Several Australian provenances of Eucalyptus camaldulensis and E. tereticornis were seen to perform better in field trials than seedlots of the Indian land race (Chaturvedi et al., 1989; KumaraVelu et al., 1995). Domestication of eucalypts in India was given a new thrust with fresh introductions to initiate breeding programs for improving the productivity (DORAN et al.,

1) Institute of Forest Genetics and Tree Breeding, Coimbatore 641002, India.

2) Department of Forest Genetics and Plant Physiology, Swedish University of Agricultural Sciences, SE 901 83, Umeå, Sweden.

*) Communication author: Phone: +91-422-2431-540, Fax: +91422-2430-549. E-mail: mvarghese1@rediffmail.com
1996). Pedigreed and unpedigreed seedling seed orchards were established in representative sites to evaluate the growth performance of the seedlots followed by thinning of inferior trees for quality seed production (HEGDE and VARGHESE, 2002). Natural seedlots of $E$. tereticornis have poor flowering in peninsular India (PINYOPUSARERK and HARWOOD, 2003a) and Sri Lanka (ARNOLD, 1996).

Seedling seed orchards have been commonly used as production populations in breeding programs for short rotation tropical eucalypts (ELDRIDGE et al., 1993). Open pollinated seedlots of selected natural provenances have been used to initiate breeding programs. Seed orchards are expected to generate genetically good seeds and constitute a reliable, controllable and reproducible seed source. Depending on the fertility and mating pattern in the orchard trees, the seed crop may vary in diversity and vigor. Differential contribution of trees has an impact on gene diversity of the orchard crop. The effective population size gives an indication of the diversity of progeny from an orchard. Fertility observations can be used for comparing the reproductive output and variation between trees in seed orchards with the base populations from which they originate (BILA, 2000; KANG, 2001; BILIR et al., 2003). Comparison of reproductive output in orchard entries with the base population would help to understand the loss of diversity during genetic improvement and the domestication process. Fertility variation will contribute to rapid accumulation of relatedness and subsequent inbreeding in species with mixed mating systems (BILA, 2000; KANG, 2001). The relationship between the effective number of parents, status number and effective number in the variance sense has been well documented by KANG and LINDGREN (1998, 1999), KJAER (1996) and KJAER and WELLENDORF (1997). The objective of this study was to evaluate fertility variation among trees in first generation unpedigreed seedling seed orchards established at different locations and to estimate the expected gene diversity of the seed crop. The study also aims to quantify the reproductive output of orchard trees at two different environments in peninsular India.

\section{Materials and Methods}

The seedling seed orchards

Two seeding seed orchards each of $E$. camaldulensis and E. tereticornis located in a moist site, Panampally $\left(10^{\circ} 52^{\prime} \mathrm{N}, 76^{\circ} 46^{\prime} \mathrm{E}, 1400 \mathrm{~mm}\right.$ rainfall, Kerala state $)$ and an arid location, Pudukkottai $\left(10^{\circ} 53^{\prime} \mathrm{N}, 78^{\circ} 49^{\prime} \mathrm{E}\right.$, $750 \mathrm{~mm}$ rainfall, Tamil nadu) in southern India were used for the study (Table 1). The seedling seed orchards were established in 1996 as a short-term strategy 
Table 1. - Location, edaphic and climatic details of orchards sites.

\begin{tabular}{|l|ll|}
\hline Location & Panampally & Pudukkottai \\
\hline Latitude & $10^{\circ} 52^{\prime} \mathrm{N}$ & $10^{\circ} 53^{\prime} \mathrm{N}$ \\
\hline Longitude & $76^{\circ} 46^{\prime} \mathrm{E}$ & $78^{\circ} 49^{\prime} \mathrm{E}$ \\
\hline Altitude (m) & 400 & 180 \\
\hline Annual rainfall (mm) & 1400 & 750 \\
\hline Soil type & Clay loam & Red Sandy Loam \\
\hline $\begin{array}{l}\text { Annual (minimum -maximum) } \\
\text { Temperature range }\left({ }^{\circ} \mathrm{C}\right)\end{array}$ & $22-39$ & $21-42$ \\
\hline
\end{tabular}

(DoRAN et al., 1996) using bulked seed from more than 500 selected trees of natural Australian provenances (like Petford, Emu Creek, Gilbert, Kennedy, Laura and Morehead Rivers and Katherine provenances of E. camaldulensis and Mt. Carbine, Helenvale, and Mt. Garnet of E. tereticornis) for meeting the immediate seed requirement. The same seed lots were used for establishing the seed orchards at both the locations. After initial establishment at $3 \times 1.5 \mathrm{~m}$ spacing the stands were subjected to two thinnings by four years of age to achieve a final spacing of about $7 \mathrm{~m}$ between trees at the time of the study (HEGDE and VARGHESE, 2002). Growth evaluation and thinning are usually completed in eucalyptus orchards by fourth year, when the orchard is normally ready for operational seed production (Meskimen and Francis, 1990). Fertility of the trees was assessed at eight and nine years of age by quantifying the flowers and fruits produced by each tree (VARGHESE et al., 2002). Diameter at breast height (Dbh) was measured for all the trees at eight years of age.

\section{Reproductive biology}

The Eucalyptus flower has about 200-250 stamens and a single stigma attached to a receptacle, covered by a lid or operculum. When the flower opens, the operculum is detached, revealing the stamens. The receptacle becomes woody after fertilization and develops into a fruit. After about three months of maturity, the fruit dehisces shedding large number of tiny, developed and sterile seeds. The flowers are principally insect pollinated, mostly by honeybees. The flowers are protandrous and adapted for cross-pollination but are capable of selfpollination also. Pollen shedding is usually completed within 24 hours of unfolding of the stamens. The stigma however becomes receptive only after about 4-7 days of opening of the flower. Thus cross pollination is favored, but there are chances of self pollination when pollen are transferred from a younger flower to an older one in the same tree or inflorescence (VENKATESH and KEDHARNATH, 1965).

\section{Assessment of flowering}

Flower and fruit production in the trees were recorded for two consecutive years - 2004 and 2005. An assembled aluminum ladder with a platform and wheels was used to go up to the top of the tree and record data with the help of binoculars. The number of primary, sec- ondary and tertiary branches was counted in each tree and the flowers per tertiary branch were recorded for all the trees during periodic visits in the peak flowering period of October-November. The number of fruits per secondary branch was recorded in two visits during the period of seed collection (May-June). Estimates of number of fruits and flowers per tree were obtained by extrapolating the counts made on flowers and fruits (BILA et al., 1999; KANG and LiNDGREN, 1998).

\section{Theory and Methods}

The theory developed by LINDGREN and MULLIN (1998) and KANG et al. (2001) for seed orchards was used for this study. Group coancestry $(\Theta)$ is the probability that two genes taken at random from the gene pool of the expected seed orchard crop will be identical by descent. Group coancestry applied for a diploid population is the average of all coancestry values between population members (including self-coancestry), but as group coancestry depends only on the gene pool and not how it is organized into individuals, the group coancestry concept can as well be applied to successful gametes before they form diploid zygotes (LINDGREN and MulLin, 1998).

Since the seed used for establishing the unpedigreed stand originated from an equal mix of a wide base of more than 500 trees and the inferior trees resulting from related mating in native stands would be eliminated in the nursery and during thinning, the orchard trees were considered to be non related and non-inbred. Although even rather small deviations from these assumptions may matter for some of the statistics developed, the statistics refers to changes compared to a state which can be described as "the wild population", "the starting material" or "reference population", and is thus relevant. All pairwise coancestries were thus considered to be equal to zero and all self-coancestries equal to 0.5 and the group coancestry is calculated as

$$
\Theta=0.5 \sum_{i=1}^{N} p_{i}^{2}
$$

where $p_{i}$ is the probability that genes sampled at random from the gamete pool originate from genotypes $i$.

The fertility of each tree was used as the probability of contribution of each genotype in determining the group coancestry $(\Theta)$, which can be obtained by adding all possible pairings of gametes from orchard trees. The share of a flower and fruit on male and female gamete produc- 
tion was assumed to be the same as there is a high correlation in eucalypts between male and female fertility of each tree (VARGHESE et al., 2002)

Status number $\left(N_{s}\right)$ is the number of non-inbred unrelated genotypes sampled from the reference population that are expected to experience the same deviation in gene frequencies from the reference population as the population under study (KANG et al., 2001). Status number (effective population size) is half the inverse of group coancestry. It is also computed as

$$
N_{s}=\frac{1}{\sum_{i=1}^{N} p_{i}^{2}}=\frac{0.5}{\theta}
$$

where $p_{i}$ is the contribution from individual genotype $i$ to the gamete pool, computed on the basis of flower and fruit counts and $N$ the census number of trees in the orchard.

These two parameters were used to estimate the diversity level in orchards. The relative population size $\left(N_{r}\right)$ was used to compare the effective number of trees contributing to random mating with the actual number of trees in the orchard $(N)$.

$$
N_{r}=\frac{N_{s}}{N}
$$

Sibling coefficient $(\Psi)$, which is the probability that two genes originate from the same parent „compared to a panmictic situation", was used to quantify the fertility differences between orchard genotypes.
Sibling coefficient can be calculated in terms of the total number of trees and the group coancestry. Thus sibling coefficient 2 means that the probability is double as high as if the genes were taken from the parent population or the progeny after panmixis.

$$
\Psi=2 \mathrm{~N} \Theta
$$

Variance effective population size $\left(N_{e}^{(v)}\right)$ was computed as the size of a population that would give the same drift in gene frequencies in the seed crop compared to the orchard parents (KANG et al., 2001).

$$
N_{e}^{(v)}=\frac{\psi}{2 \Theta(\psi-1)}
$$

Variance effective population size $\left(N_{e}^{(v)}\right)$ describes how the gene frequencies (in neutral genes) are expected to change (drift) between orchard parents and the seed (KANG et al., 2001) crop.

Gene diversity $(G D=1-\Theta)$ was estimated in terms of group coancestry (KANG et al., 2003). The trees were assumed to be unrelated and non-inbred. This can be seen as that they are a sample from the reference population where by definition all trees are unrelated. Group coancestry can be regarded as a measure of gene diversity lost during tree breeding operations.

\section{Results}

The details of orchard stocking, growth and fertility in different locations at eight and nine years of age are

\begin{tabular}{|c|c|c|c|c|c|c|c|c|}
\hline Species & \multicolumn{4}{|c|}{ Eucalyptus camaldulensis } & \multicolumn{4}{|c|}{ Eucalyptus tereticornis } \\
\hline Location & \multicolumn{2}{|c|}{ Panampally } & \multicolumn{2}{|c|}{ Pudukkottai } & \multicolumn{2}{|c|}{ Panampally } & \multicolumn{2}{|c|}{ Pudukkottai } \\
\hline $\begin{array}{l}\text { Area of seed orchard } \\
\text { (ha) }\end{array}$ & 1 & 1 & 3 & 3 & 1 & 1 & 3 & 3 \\
\hline Age (years) & 8 & 9 & 8 & 9 & 8 & 9 & 8 & 9 \\
\hline $\begin{array}{l}\text { Average } \mathrm{Dbh} \pm \\
\qquad \text { Std deviation }(\mathrm{cm})\end{array}$ & $\begin{array}{r}15.43 \pm \\
2.2\end{array}$ & - & $\begin{array}{r}12.57 \pm \\
1.5\end{array}$ & - & $\begin{array}{r}14.3 \pm \\
2.1\end{array}$ & - & $\begin{array}{r}12.47 \pm \\
1.8\end{array}$ & - \\
\hline $\begin{array}{l}\text { Fruits per tree } \pm \\
\qquad \text { Std deviation }\end{array}$ & $\begin{array}{r}3939 \pm \\
4406\end{array}$ & $\begin{array}{r}5114= \\
7595\end{array}$ & $\begin{array}{r}1195 \pm \\
2861\end{array}$ & $\begin{array}{r}764 \pm \\
1612\end{array}$ & $\begin{array}{r}328 \pm \\
1150\end{array}$ & $\begin{array}{r}227 \pm \\
743\end{array}$ & $\begin{array}{r}1674 \pm \\
4689\end{array}$ & $\begin{array}{r}978 \pm \\
1882\end{array}$ \\
\hline Number of trees $(\mathrm{N})$ & 182 & 182 & 525 & 525 & 192 & 192 & 505 & 505 \\
\hline Fertile trees $(\%)$ & 73.1 & 82.4 & 25.9 & 44.6 & 23.4 & 15.1 & 28.3 & 50.5 \\
\hline$\Theta^{\perp}$ & 0.0062 & 0.0088 & 0.0064 & 0.0052 & 0.0305 & 0.0349 & 0.0084 & 0.0052 \\
\hline$N s^{2}$ & 80.64 & 56.81 & 78.12 & 96.15 & 16.39 & 14.32 & 59.52 & 96.15 \\
\hline$N r^{3}$ & 0.445 & 0.313 & 0.148 & 0.184 & 0.085 & 0.075 & 0.118 & 0.191 \\
\hline $\mathrm{Ne}(\mathrm{v})^{4}$ & 144.81 & 82.60 & 91.78 & 117.71 & 17.92 & 15.48 & 67.47 & 118.76 \\
\hline$\Psi^{5}$ & 2.27 & 3.20 & 6.72 & 5.46 & 11.71 & 13.40 & 8.48 & 5.25 \\
\hline$G D^{6}$ & 0.9938 & 0.9912 & 0.9936 & 0.9948 & 0.9690 & 0.9650 & 0.9916 & 0.9948 \\
\hline
\end{tabular}
given in Table 2. Both species of eucalypts had better

Table 2. - Details of tree growth, fruit yield and estimates of fertility variation and gene diversity in four thinned seedling seed orchards of eucalypts.

1-Group coancestry, 2-Status number, 3-Relative effective population size, 4-Variance effective population size, 5 -Sibling coefficient, 6 -Gene Diversity. 
Table 3. - Phenotypic correlation between diameter growth and fruit production (2004 and 2005) among trees in eucalyptus seedling seed orchards.

\begin{tabular}{|c|c|c|c|c|}
\hline \multirow[t]{3}{*}{ Trait } & \multicolumn{2}{|c|}{ Panampally } & \multicolumn{2}{|c|}{ Pudukkottai } \\
\hline & E. camaldulensis & E. tereticornis & E. camaldulensis & E. tereticornis \\
\hline & Dbh $\quad$ Fruits 05 & Dbh Fruits 05 & Dbh $\quad$ Fruits 05 & Dbh Fruits 05 \\
\hline Dbh & $0.384^{*}$ & $0.394^{*}$ & $0.184^{*}$ & $0.207^{*}$ \\
\hline Fruits 04 & $0.196^{*} \quad 0.421^{*}$ & $0.240^{*} 0.386^{*}$ & $0.004^{\mathrm{n} . \mathrm{s}} \quad 0.290^{*}$ & $0.158^{*} 0.147^{*}$ \\
\hline
\end{tabular}

n. s. $=$ not significant, $*=\mathrm{P}, 0.05$.

growth in the moist site than in the dry location. In the dry location at Pudukkottai, both species had similar growth whereas $E$. camaldulensis had better growth than $E$. tereticornis in the moist site.

\section{Reproductive status of orchards}

The two eucalypt species differed considerably in fertility status in the moist site. More than $73 \%$ of $E$. camaldulensis trees were fertile in this site in contrast to less than $25 \%$ fertile trees in E. tereticornis. The same trend was obtained in fertility observations made for two consecutive years (age eight and nine years). At the dry location both species had the same fertility pattern across two consecutive years. Around 25\% trees were fertile at eight years. There was almost twice the number of fertile trees $(50 \%)$ in the next year.

The number of fruits produced per tree also followed a similar pattern. Fruit production was quite high (4000-5000 per tree) in E. camaldulensis at the high rainfall site whereas it was quite low (300 fruits per tree) in E. tereticornis. Even though the trend was the same in both years the fruit production in E. camaldulensis was higher in the second year than that in the first year. Compared to the differences in fruit production in the moist site the two species had more or less similar fertility in the dry site with greater reproductive output in the first year (eight years). Tree diameter had weak positive correlation with fruit production (ranging from 0.004 to 0.394 ) and it was comparatively low in the first year than in the second year (Table 3). The correlation was higher in the moist site at Panampally than at Pudukkottai even though the number of fertile trees was quite low in E. tereticornis at the former site. In general the fruit production was positively correlated among consecutive years (there was higher correlation in the moist site than in the dry location for both species).

\section{Fertility variation and effective population size}

Fertility variation was low in the $E$. camaldulensis orchard at Panampally as indicated by the sibling coefficient values ( $\Psi=2 \& 3$ ) whereas it was unusually high for $E$. tereticornis in the same site ( $\Psi=11 \& 13)$. In the dry Pudukkottai site both species had more or less similar fertility variation ( $\Psi=5$ to 8 ). Even though there were almost three times more trees in the dry location, the effective population size (status number) in E. camaldulensis orchards was almost the same at both sites since almost $45 \%$ of the trees contributed effectively to seed production in the moist site in comparison to a mere 15 to $18 \%$ effective contribution at the other site. Both species had more or less the same effective population size at Pudukkottai (Table 2). Since many E. tereticornis trees did not flower at the moist site, there were only about sixteen effectively contributing trees resulting in a low variance effective population size and high genetic drift. The variance effective population size was around 100 for the other orchards in both locations. It has been observed that when fertility is more even among trees (low sibling coefficient value) the higher the fertility is (Fig. 1). The coancestry values were low for all the orchards except in the E. terticornis orchard at Panampally. Thus the gene diversity of the seed crop was also adequate $(>0.99)$ in the other orchards at both locations and the orchards had more than 50 equally contributing trees (status number) in two continuous years. There was not much difference in trend in observations made for two consecutive years.

\section{Discussion}

\section{Fertility in eucalypt orchards and species}

The present study has revealed that there is a low positive correlation between fertility and tree diameter

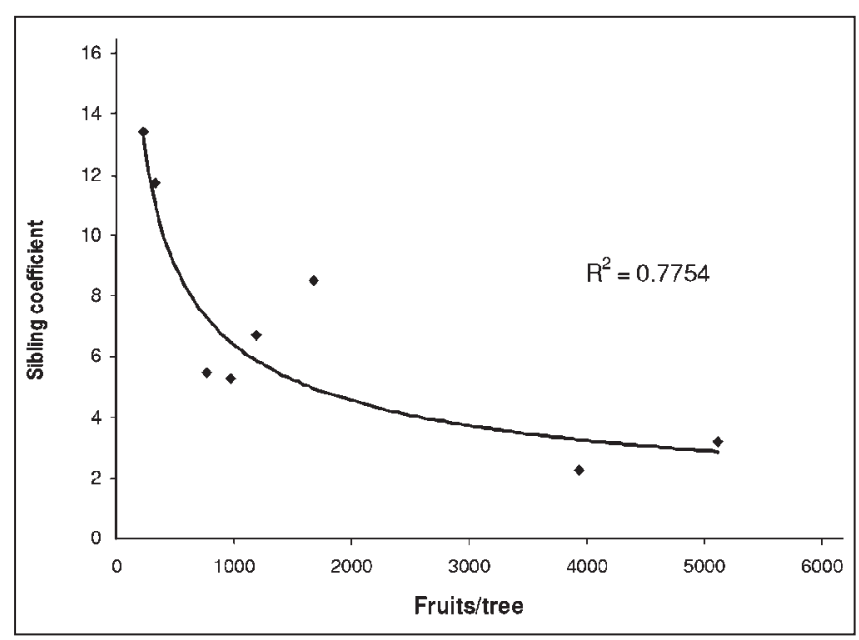

Figure 1. - Relationship between sibling coefficient $(\Psi)$ and fruits/tree in seedling seed orchards of eucalypts. 
in the orchards (except in 2004 in $E$. camaldulensis at Pudukkottai). Fertility is not a problem in land races of eucalypts and casuarina (VARGHESE et al., 2002, 2004) but would be an important trait for consideration in first generation introductions of natural provenances. Poor fertility has been reported in E. tereticornis stands in tropical moist environments (PINYOPUSARERK and HARWOOD, 2003a; ARNOLD, 1996) in Asian countries. High fertility variation has also been reported in a pedigreed $E$. tereticornis seedling seed orchard in Tamil nadu (VARGHESE et al., 2002). KANG et al. (2003) reported an average $\Psi$ value of 2.62 for seed orchards of broadleaved species. Generally sibling coefficient values may be high in young orchards and during poor flowering years (KANG et al., 2003). The current study reveals that the Panampally site is suitable for locating $E$. camaldulensis seed orchards ( $\Psi=2.27$ and 3.20). This has been confirmed by the near similar pattern of fruit production in two consecutive years. Very poor flowering and seed production in this species has however been reported in locations receiving high precipitation $(>2000 \mathrm{~mm}$ ) in Philippines and Vietnam (PINYOPUSARERK and HARWOOD, 2003a).

\section{Gene diversity of seed orchards}

Progeny originating from orchards of the same seed origin could vary depending on the flowering status and the fertility variation between trees. Excessive fertility of a few trees can lead to relatedness among progeny and loss of diversity occurs from increase in coancestry levels in the orchard as a result of variable flowering among trees. The problem can be very acute if the number of flowering trees is very low. Poor and irregular flowering is often observed in orchards that are not located on good flowering sites, and even on good sites, micro-site influences are important (SWEET, 1992). The total precipitation and the rainy days in each year would also have an impact on fertility of trees. Higher precipitation than normal average $(921 \mathrm{~mm}$ in 2004 and $1360 \mathrm{~mm}$ in 2005 at Pudukkottai and $1727 \mathrm{~mm}$ in 2004 and $2011 \mathrm{~mm}$ in 2005 at Panampally) was received in both locations during the study period. Thus the fertility observations need to be recorded every year before seed collection to ensure adequate diversity and outcrossing in the seed crop. The correlation between fruit production in successive years is low indicating that the trees flowering abundantly in one year are not those which produce abundant offspring the next year. Mixing of seeds from consecutive crops would thus increase gene diversity in the crop. In orchards like that of E. camaldulensis at Panampally where number of fertile trees and fruit production per tree is very high and fertility variation is low, the genetic quality and diversity of the progeny will not be a concern as the mating pattern and the contribution from superior trees are ensured.

To obtain a certain effective population size more trees are needed under conditions when the fertility and seed set is lower. Thus the current study indicates that big orchards with large number of trees can be effective in ensuring diversity in the seed crop as seen in the dry location at Pudukkottai. From a survey of several eucalypt seed orchards in Asian countries, PiNYOPUSARERK and HARWOOD (2003b) recommended that seed collection could be done in orchards where $50 \%$ of the trees are fertile. Three of the orchards in the current study have recorded more than $46 \%$ fertile trees and may be considered suitable for seed production. In the dry Pudukkottai site even if the relative contribution of trees is low, an effective population size almost on par with the highly fertile E. camaldulensis orchard at Panampally is achieved, (since there are more than 500 trees each in the orchards) which would ensure adequate outcrossed progeny. That fruit production of the trees is not closely correlated among consecutive years indicates that it is difficult to make prognosis for the reproductive output of trees over a life cycle based on observations made in individual years. The contribution of the parent trees to the offspring will however vary less between years than between individual orchards since the sibling coefficient is more or less similar between years. Thus it would be necessary to do a fertility assessment at least once in the productive age of an orchard.

\section{Implications in eucalypt breeding program}

Unpedigreed breeding populations are established as a short-term strategy in the eucalypt breeding program where genetic diversity is given emphasis over the gain obtained from between and within family selection in pedigreed orchards (DoRAN et al., 1996). Selection and recombination are the key activities in a breeding program. They are expected to accumulate genes, which influence yield and adaptation by increasing the frequency of the superior trees over successive generations.

Gains up to $20 \%$ are anticipated over and above those from provenance selection once the pedigreed breeding population gets converted to a seedling seed orchard (DoRAN et al., 1996). The gain expected from thinned unpedigreed seedling seed orchards is about the same as that obtained from a first generation pedigreed seedling seed orchard of the long term breeding program (SHELBOURNE, 1992). Gains beyond the first generation would depend on the accuracy in selecting the best genotypes and management of inbreeding in the seed orchards. Gains will be cumulative in the first and subsequent generations. Selection up to three generations if carried out are expected to provide plantations whose average productivity exceed those established from local sources or seeds obtained from natural stands.

It can be inferred from the current study that a conservative strategy to maintain adequate diversity would be necessary in first generation orchards of eucalypts, where trees are in early stages of domestication, to sustain improvement in subsequent generations. Factors like genetic drift and inbreeding play an important role in deciding the subsequent benefits. Thus it is imperative that breeding for high productivity be complimented by maintaining a large breeding population representing low intensity breeding in a lower tier of wider diversity (LINDGREN, 2000). Unpedigreed seed production areas are often established with a mixture of half sib families, identified mostly on phenotypic performance, to compliment family identified breeding populations which have fewer families selected on family merit (HARWOOD et al., 1996). Large differences in fertility 
among trees are common in natural populations (BILA and LINDGREN, 1998) and in plantations (BILA et al., 1999) under tropical conditions. High fertility variation usually found in eucalypt seedling seed orchards indicate that eucalypts introduced to exotic environments are more variable, particularly $E$. tereticornis, in fertilities than typical and need to be assessed carefully before resorting to seed collection. But it may be noted that the status number and gene diversity get fairly high values in spite of the fertility variations among trees. Thus 200 unrelated trees could be expected to be sufficient for a seedling seed orchard if more than $50 \%$ of the trees are fertile. If the stands arising from a seed orchard should be the major base for continued breeding it seems recommendable to have a status number above 50 , which is obtained for three of the four seed orchards in this study.

\section{Acknowledgment}

International Foundation for Science, Sweden (IFS) supported this study by providing a research grant (D/3236) to Mohan Varghese. Dr. Chris Harwood of CSIRO, Australia provided technical support for the eucalypt breeding program in India.

\section{References}

ARNOLD, R. J. (1996): Eucalyptus Genetic improvement strategies - prepared for Sri Lanka Forest Department (unpublished report). Australian Tree Seed Centre, CSIRO, Canberra.

BilA, A. D. (2000): Fertility variation and its effects on gene diversity in forest tree populations. $\mathrm{PhD}$ thesis. Swedish University of Agricultural Sciences. Umeå Sweden. Acta Universitatis Agriculturae Sueciae 166.

BILA, A. D. and D. LINDGREN (1998): Fertility variation in Milletia sthulimannii, Brachystegia speciformis, Brachystegia bohemi and Leucaena leucocephala and its effects on relatedness in seeds. For. Gen. 5: 119-129.

BilA, A. D., D. LindGREN and T. J. Mullin (1999): Fertility variation and its effect on diversity over generations in a teak plantation (Tectona grandis L.f) Silvae Genet. 48: 109-114.

BILIR, N., K. S. KANG and D. LindGREN (2003): Fertility variation and effective number in the seed production areas of Pinus radiata and Pinus pinaster. Silvae Genet. 52(2): 75-77.

Chandra, K. M., S. S. Patnaik and K. Gurumurthi (1992): Country report India. In: Tree Breeding and Propagation. Part II Regional Review and Country Reports. Field Document No.2, Fao/ Undp Project Ras/88/025, Bangkok, Pp. 49-68.

Chaturvedi, A. N., P. Sivaji and D. V. Jayaramprasad (1989): Eucalyptus provenance trials in Andhra Pradesh. Ind. For. 115, 445-454.

Doran, J. C., K. Pinyopusarerk, R. Arnold and C. E. HARWOOD (1996): Breeding Plan for Eucalyptus camaldulensis in Tamil nadu. UNDP/FAO Regional Project on Improved Productivity of Man Made Forests Through Application of Technical Advances in Tree Breeding and Propagation (RAS/91/004 - FORTIP), FAO, Los Banos, Phillipines, 40p.

Eldridge, K. G., J. Davidson, C. E. Harwood and G. van WYK (1993): Eucalypt Domestication and Breeding, Clarendon Press, Oxford.
Harwood, C. E., D. G. Nikles, P. Pomeroy and K. A. RoBSON (1996): Impact of thinning via phenotypic selection on the genetic base of planted seed production areas. In: Dieters, M. J., Matheson, A. C., Nikles, D. G., HarWoOD, C. E. and WALKer, S. M. (Eds.). Tree Improvement for Sustainable Tropical Forestry. Proc. QFRIIUFRO conference. Caloundra, 27 Oct.-1 Nov. 1996, Vol. 2, pp 148-153.

Hegde, R. and M. VARghese (2002): Selection and thinning in an unpedigreed seedling seed orchard of Eucalyptus camaldulensis Dehn. In: BAGCHI, S. K., VARGHESE, M. and SIDDAPPA (Eds.). Recent Eucalypt Research in India. Indian Council of Forestry Research and Education, Dehra Dun. pp 9-18.

KaIKINI, N. S. (1961): Eucalyptus in Mysore state. Proceedings of the tenth All India Silvicultural Conference, Dehra Dun, pp 546-553.

KANG, K. S. (2001): Genetic gain and gene diversity of seed orchard crops. PhD thesis, Department of Forest Genetics and Plant Physiology, Swedish University of Agricultural Sciences, Umeå.

KANG, K. S. and D. LindGREN (1998): Fertility variation and its effect on the relatedness of seeds in Pinus densiflora, $P$. thunbergii and $P$. koraiensis clonal seed orchards. Silvae Genet. 47: 196-201.

KANG, K. S. and D. D. LINDGREN (1999): Fertility variation among clones of Korean pine (Pinus koraiensis) and its implications on seed orchard management. For. Gen. 6(3): 191-200.

Kang, K. S., A. D. Bila, A. M. HarJu and D. Lindgren (2003): Estimation of fertility variation in forest tree populations. Forestry 76(3): 329-344.

KANG, K. S., D. LindGren and T. J. Mullin (2001): Prediction of genetic gain and gene diversity in seed orchard crops under alternative management strategies. Theor. Appl. Genet. 103: 1099-1107.

KJAER, E. D. (1996): Estimation of effective population number in a Picea abies (Karst.) seed orchard based on flower assessment. Scand. J. For. Res. 11: 111-121.

KJAER, E. D. and H. WellendoRF (1997): Variation in flowering and reproductive success in a Danish Picea abies (Karst.) seed orchard. For. Gen. 4: 181-188.

Kumaravelu, G., S. JagdeEs, R. S. V. RAi and B. SAmpson (1995): Provenances of Eucalyptus camaldulensis Dehnh and E. tereticornis Sm suitable to South Indian conditions - results of an IUFRO trial. Ann. For. 3: 129-133.

LINDGREN, D. (2000): Low intensity breeding. In: LuNDKVIST, K. (Ed). Rapid generation turnover in the breeding population and low-intensity breeding. Department of Forest Genetics, Swedish Agricultural University, Uppsala, Sweden, Research Notes 55: 37-48.

LindGren, D. and T. J. Mullin (1998): Relatedness and status number in seed orchard crops. Can. J. For. Res. 28: 276-283.

Meskimen, G. and J. K. Francis (1990): Rose gum Eucalyptus. In: BuRns, R. M. and Honkala, B. H. (Eds.). Silvics of North America Vol. 2. Hardwoods, Agricultural Handbook 654. USDA Forest Service, Washington DC $877 \mathrm{p}$.

Midgley, S. J., J. W. Turnbull and K. Pinyopusarerk (2002): Industrial Acacias in Asia: Small brother or big competitor? In: WEI, R. P. and XU, D. (Eds.). Proc. International Symposium on Eucalyptus Plantations, September 1-6, 2002, Guangdong, China, pp 19-36. 
Pinyopusarerk, K. and C. E. Harwood (2003a): Surveys of seed orchards of key Australian tree species. Client Report No. 1242. CSIRO Forestry and Forest Products, Australia.

Pinyopusarerk, K. and C. E. HARWOOD (2003b): Flowering and seed production in tropical Eucalyptus seed orchards. In: TuRnBulL, J. W. (ed.). Eucalypts in Asia. ACIAR proceedings No. 111. Australian Centre for International Agricultural Research. Canberra. pp 247-248.

Shelbourne, C. J. A. (1992): Genetic gains from different kinds of breeding population and seed or plant production population. Sth. Afr. For. J. No. 160: 49-60.

SweEt, G. B. (1992): Seed Orchard Research and Management in the 1990s-A New Zealand Case study. In syntheses of IUFRO meeting on Mass Production for
Genetically Improved Fast Growing Forest Tree Species. AFOCEL, Paris, France, pp 110-118.

VArghese, M., D. Lindgren and A. Nicodemus (2004): Fertility and effective population size in seedling seed orchards of Casuarina equisetifolia and C. junghuhniana. Silvae Genet. 53: 141-192.

VARGhese, M., N. RAVI, S. G. Son and D. LindGren (2002): Variation in fertility and its impact on gene diversity in a seedling seed orchard of Eucalyptus tereticornis. In: WeI, R. P. and XU, D. (eds.). Eucalyptus plantationsResearch, Management and Development. World Scientific, Singapore. pp 111-126.

Venkatesh, C. S. and S. Kedharnath (1965): Genetic improvement of Eucalyptus in India. Silvae Genet. 14, 141-176.

\title{
Deterministic Simulation of Gains for Seedling and Cloned Main and Elite Breeding Populations of Pinus radiata and Implications for Strategy
}

\author{
By C. J. A. Shelbourne*), S. Kumar, R. D. Burdon, L. D. Gea and H. S. Dungey \\ Ensis Genetics, Private Bag 3020, Rotorua, New Zealand
}

(Received $11^{\text {th }}$ August 2006)

\begin{abstract}
Genetic gains in breast-height diameter were estimated using deterministic simulation. Simulations of gain from one generation of selection were undertaken in large Main and small Elite breeding populations for a range of heritabilities, with varying numbers of parents, families, seedlings/family, clones/family and ramets/ clone to aid revision of the New Zealand Pinus radiata breeding strategy.

Cloned versus seedling populations of equal numbers of plants were simulated, derived from open pollination, polycrossing, and pair crossing. Balanced within-family selection was used for 200, 400 and 800-parent Main breeding populations and among- and within-family selection for 25-parent Elite populations of 25 up to 100 full-sib families.

Predicted gains from within-family selection in the Main population were highest from cloned polycross families at all heritabilities and lowest for seedling fullsib families. Gains from cloned populations were higher than seedling equivalents at heritabilities $\leq 0.5$, and their advantage in gain was greatest at lower heritabilities. Elite populations of 25 parents showed similar trends but intensive among- and within-family selection resulted in much higher gains than from the Main,
\end{abstract}

*) Corresponding author: Email: cjashelbourne@hotmail.com. highest from the cloned options. The increase in gain with increased number of families diminished with more than 2-3 times as many families as parents.

A new strategy was proposed for $P$. radiata, based on the simulation results, involving an expanded Main breeding population of open-pollinated (OP) seedling families, together with pair-cross family seedlots already available, supported by parentage reconstruction using DNA markers. Forwards selection in small cloned Elite populations was proposed as the main source of seed orchard clones.

Key words: breeding populations, deterministic simulation, genetic gain, cloning, open-pollination, controlled pollination, backwards selection, forwards selection, seed orchard, Pinus radiata.

\section{Introduction}

When designing a breeding strategy for the genetic improvement of any species, one must have some means of predicting the amount of genetic improvement that will result from alternative strategies and population structures. Stochastic simulation is best for predicting gain over several generations, as well as predicting population means, size of additive variance, amount of inbreeding and effective population size or status number (LINDGREN et al., 1996), but requires making multi- 